\title{
Eğitim Fakültesi Öğrencilerinin Kariyer Stresleri, Kariyer Uyum Yetenekleri ve Mentörlük Arasındaki İlişkinin İncelenmesi
}

\section{Analysing the Relationship Between Career Stress, Career Adaptability and Mentorship of Education Faculty Students}

\author{
Hazel DURU ${ }^{1}$, Filiz GÜLTEKIN²
}

Öz

Günümüzde iş yaşamındaki hızlı değişimlerle birlikte üniversite öğrenimini sürdüren bireylerin mezun olduktan sonra kariyerlerine ilişkin nasıl bir yol izleyecekleriyle ilgili sorunları artmaktadır. Üniversite öğrencilerinin seçtikleri kariyere uyum sağlayabilmeleri, kariyerlerini oluştururken kendilerini etkileyen stresörleri fark etmeleri ve karşılaştıkları zorlanmalarda nasıl bir yol izlemeleri gerektiğine ilişkin bilgilere sahip olmalarını zorunlu kılmaktadır. Bu çalışmanın amacı üniversite öğrencilerinin kariyer stresleri ile kariyer uyum yetenekleri ve öğrencilere sunulan mentörlük hizmetleri arasındaki ilişkinin incelenmesidir. Çalışmaya 213 kadın 71 erkek üniversite öğrencisi katılmışır. Öğrencilerin kariyer stresi düzeylerini belirlemek için Kariyer Stresi Ölçeği, kariyer uyum yeteneklerini belirlemek için Kariyer Uyum Yeteneği Ölçeği ve mentörlük için Yükseköğretim Öğrenci Mentörlük Ölçeği kullanıımıştır. Verilerin analizinde değişkenler arasındaki ilişkiyi belirlemek için pearson momentler çarpım korelasyonu katsayısı; üniversite öğrencilerinin kariyer uyum yetenekleri ve mentörlük hizmetinin kariyer stresini açıklama gücünü belirlemek için çoklu regresyon analizi kullanılmıştır. Çalışma sonucunda kariyer stresi toplam puanı ve alt ölçekleri ile kariyer uyum yeteneği ve yüksek öğretim mentörlük ölçeği alt ölçek puanları arasında anlamlı düzeyde ilişki olduğu bulunmuştur. Kariyer Uyum Yetenekleri Ölçeğinin kaygı ve kontrol alt ölçek puanlarının Kariyer Stresi Ölçeği'nin puanını anlamlı düzeyde yordadığı belirlenmiştir. Çalışma sonucunda öğrenci dönütlerine dayalı olarak öğrencilerin kariyer stresi sebeplerinin ve kariyer stresini hangi konularda daha yoğun yaşadıklarının nitel bir çalışma ile belirlenmesinin ve kariyer danışmanlığı programı hazırlanmasının etkili olabileceği düşünülmektedir.

Anahtar Kelimeler: kariyer, kariyer stresi, kariyer uyumu, mentörlük, üniversite öğrencileri

\section{Abstract}

With rapid changes in current business life, individuals in university education have increasing problems regarding which way to follow in their career after graduation. This forces university students to adapt to the career they choose, realise stressors that affect them when they are forming their career and which way to go when they face challenges. The purpose of this study is to analyse the relationship between career stress, career adaptability and mentorship services offered to university students. 213 female and 71 male university students participated in this study. The Career Stress Scale is applied to determine career stress levels of students, Career Adaptability Scale is applied to determine career adaptability and Higher Education Student Mentorship Scale is applied for mentorship. In data analysis, the Pearson product-moment correlation coefficient is used to determine the relationship between variables; multiple regression analysis is used to determine how well career adaptability and mentorship services explained career stress. The results of this study showed that there is a significant relationship between the career stress total score and sub-scale and career adaptability and higher education mentorship sub-scale scores. It is determined that anxiety and control sub-scales of career adaptability scale predicted career stress scale scores at a significant level. Based on the results of this study, it is believed that it can be beneficial to determine the causes of career stress and where do students experience intense career stress with a qualitative study based on the feedback of students and to prepare a career consultancy program.

Keywords: career, career adabtability, career stress, mentorship, university students

\footnotetext{
${ }^{1}$ Uludağ Üniversitesi, Bursa, Türkiye, https://orcid.org/0000-0002-1669-6407

${ }^{2}$ Uludağ Üniversitesi, Bursa, Türkiye, http://orcid.org/0000-0002-6281-3096

Atıf / Citation: Duru, H., \& Gültekin, F. (2020). Eğitim fakültesi öğrencilerinin kariyer stresleri, kariyer uyum yetenekleri ve mentörlük arasındaki ilişkinin incelenmesi. Kastamonu Education Journal, 28(1), 328-337. doi:10.24106/kefdergi.3596
} 


\section{Extended Abstract}

Introduction.Careers are an element that impacts other roles in an individual's life as well as living standards and the future. Recently, rapid changes in business life, performance and skill-focused employer institutions and managers emphasize adaptability to innovations (Bagshaw, 1998) and this leads to the adaptability of university students in their career choice, realising stressors that affect them and which way to follow when they face challenges. In career structuring theory, career development is defined as the transition of individuals from school to business life, realising change between two workplaces and adaptability to an environment (Savickas, 1997). Since people develop their career throughout their life, people should work in professions where they can apply their skills and update these skills in changing business life.

Career adaptability consists of four dimensions, namely career interest, career anxiety, career control and career trust (Savickas and Porfeli, 2012). Career interest contains positive evaluations related with future responsibilities of an individual (Savickas, 1991). Career control is self-regulation for the future and taking responsibility to choose a profession (Brown and Brooks, 1991); career interest is evaluating the education and professional options (Blustein, 1992); career trust is to selfsufficiently consider and solve problems (Hartung, Porfeli and Vondracek, 2008). University students are in a transition process form school life to business life. The university period is an important period to make career planning for future and educational life where career indecisiveness is high (Özden and Sertel- Berk, 2017). Students are stressed since they face multiple tasks and the majority of the students struggle on topics related with their careers (Fouad, 2006). Changes in life, increasing competition, employment problems and similar career struggles and emotional struggles (anxiety, stress etc.) may lead individuals to need a guide for their career. At this point, mentorship that helps individuals as a career consultant and affects young employees and their system is mentioned (Mc-Mahon, Patton, 2000). In this relationship, called mentorship, a reciprocal and cooperative process is experienced between a knowledgeable person (mentor) and individuals who lack experience and need guidance (mentee).

When the literature was reviewed, there are no studies analysing the relationship between career stress, career adaptability and mentorship that is offered to university students. In this sense, this is an original study. Higher education students must realise both academic and career development related tasks due to the nature of this period. When considering the high stress level of students and that career adaptability involves cooing, problem solving skills, adapting to change, and decision making, identifying relationship between concepts in career development of students will help planning practices for career development of students.

Method.This study was applied with quantitative research methods. The correlation model was adopted to analyse the relationship between career stress, career adaptability and mentorship offered to university students. The sample of this study consisted of a total of 284 ( 213 female, 71 male) university students in psychological counselling and guidance, classroom teaching, special education teaching, English teaching, German teaching, mathematics teaching, computer and learning technologies teaching, social science teaching, Turkish teaching departments of education faculties of two state universities. As a data collection tool, the 20-item Career Stress Scale developed by Choi et al. (2011), the 19-item Career Adaptability Scale adapted to Turkish by Kanten (2012) and the Higher Education Mentorship Scale adapted to Turkish by Gök and Aydın (2017) were used. Pearson product-moment correlation analysis was used for determining the relationship between variables; multiple regression analysis was used for determining how well career adaptability and mentorship services explained the career stress of university students.

Findings. The results of this study showed a significant relationship between career adaptability, career stress and mentorship service offered to university students $(p<.01,05)$. It was determined that career adaptability and higher education student mentorship predicted career stress at a significant level. It was determined that anxiety and control sub-scale scores of CAS explained $18 \%$ of total variance of CSS.

Discussion and Results. The results of this study determined a significant relationship between career adaptability, higher education mentorship and career stress. Similar to these findings, Stoltz, Wolf, Monroe, Mazahreh and Farris (2013) found a relationship between career adaptability, coping with stress, personal characteristics, multi-directional and an unlimited thought structure. Another study expressed career related stress of university students among the top stressors (Jang, 2000; Kim, 2003; Ref. Özden, Sertel-Berk, 2017). Mathew (2017) stated that among the stress coping strategies of university students, skills to start a career and career approach is effective. However, there are no studies in domestic literature that analyses career adaptability, mentorship and career stress together. Yang et al. (2011) determined that mentorship services provided to individuals is an important factor to cope with stress. In this study, it was determined that the control and anxiety sub-scale scores of career adaptability predicted career stress. Other variables had no significant contribution to this model. As stated earlier, teaching has limited and pre-defined work definition and institutions. Students are familiar with the school system and functions due to their long years as students. Students can observe and evaluate as a teacher in schools where they do an internship and do observations and various applications. It was determined that there was low and medium level relationship between career stress and career adaptability and mentorship services; it was determined that the control and anxiety sub-scale scores of career adaptability significantly predicted career stress. To obtain comprehensive knowledge on other variables that effect career stress of studies in the education faculty, a qualitative study that has in-depth interviews can be applied on high and low students. 


\section{Giriş}

"Büyüyünce ne olacaksın?" sorusu, pek çok insanın çocukluk yıllarında mesleki seçimlerini ifade etmesine aracılık etmiş olan bir sorudur. Küçük yaşlarda öğretmen, pilot, doktor, itfaiyeci gibi hayali nitelemelerle başlayan mesleki seçim süreci, ergenlik yıllarında bireyin yaşamının geri kalan kısmını nerede, nasıl, kimlerle, ne yaparak geçireceğini belirleyen kariyer tercihleriyle devam eder.

Freud meslek yaşamının önemini ifade etmek için; "sağıklı insan çalışabilen ve sevebilen insandır." ifadesini kullanmıştır (Yeşilyaprak, 2014). Kariyer, bireyin hayatındaki diğer rollerini etkileyen ve yaşam standartlarına, geleceğine etki eden bir unsurdur. Son yıllarda iş hayatında olan hızlı değişimler, iş veren kurumların ve yöneticilerin performans ve beceri odaklı olması, yeniliklere uyum sağlayabilmenin ön plana çıkması (Bagshaw, 1998); üniversite öğrencilerinin seçtikleri kariyere uyum sağlayabilmeleri, kariyerlerini oluştururken kendilerini etkileyen stresörleri fark etmeleri ve karşılaştıkları zorlanmalarda nasıl bir yol izlemeleriyle ilgili bilgilere sahip olmaları gerekliliğini ortaya çıkarmaktadır. Bu bağlamda mezun olduktan sonra iş yaşamına geçme, istihdam olanakları, tercih edilen mesleğe yönelik ilgi, merak ve kariyer gelişimi sürecinde yapılacak yönlendirmeler önemli görülmektedir.

Kariyer, yaşam boyu gelişim yaklaşımı açısından bireyin belli yaşam dönemlerinde, farklı görevleri beraberinde getiren ve gelişimle birlikte artan görevleri açıklayan; keşfetme, kurulum, sürdürme ve aktivitede azalma olarak tanımlanan bir kavramdır (Hall, 2002). Tanımdan da anlaşılacağı üzere kariyer; belli bir dönemi kapsayan bir kavram değildir. Kariyer, hayat boyu süren, hayattaki çeşitli rollerin etkileşimi ile gelişen ve insanların iş yaşamlarındaki değişimleri de kapsayan bir süreçtir. Kariyer tanımlanırken genelde meslek ve iş kavramıyla eş anlamlı olarak kullanılmaktadır ve bu durum yanılgıya neden olmaktadır (Super, 1990).

Kariyer, bireyin toplum içindeki durumunun, kazancının, zenginlik ve yaşam tarzının güçlü bir belirleyicisidir (Johnson ve Mortimer, 2002). Kariyer yapılandırma kuramında kariyer gelişiminin; bireyin okuldan iş yaşamına geçişini, iki iş arasında değişim gerçekleştirmesini ve çevresine olan uyumunu içerdiği ifade edilmektedir (Savickas, 1997). İnsanlar yaşamları boyunca kariyer gelişimlerini sürdürdükleri için kendi becerilerini uygulayabilecekleri ve değişen iş hayatına göre bu becerilerini yenileyebilecekleri meslekleri yapmalıdır. İş ve meslek hayatındaki yenilik ve değişimlere ayak uydurma ise kariyer uyum yeteneğiyle ilgilidir (Kahya ve Ceylan, 2018).

Kariyer uyum yeteneği; ulaşılabilir fırsatları araştırmayı, geleceğe dönük planlar yapabilmeyi, uygun ve gerçekçi kararlar alabilmeyi ve bireyin amaçlarına ulaşmasını etkileyen kişisel, kişiler arası ve çevresel faktörleri yönetmeyi, öz düzenlemeyi içerir (Baumesiter ve Vohs, 2007). Başka bir şekilde tanımlanacak olursa kariyer uyum yeteneği; bireyin meslek hayatındaki görevlerle ve ön görülmez olan değişimlerle baş etme becerisidir (Savickas, 1997). Kariyer uyum yeteneği; kariyer merakı, kariyer kaygısı, kariyer kontrolü ve kariyer güveni olmak üzere dört boyuttan oluşmaktadır (Savickas ve Porfeli, 2012). Kariyer ilgisi, bireyin geleceği ve gelecekteki sorumlulukları ile ilgili pozitif değerlendirmelerini içerir. (Savickas, 1991). Kariyer kontrolü, gelecekle ve meslekle ilgili tercih yapma sorumluluğunu almak üzere oluşan öz düzenlemeyi (Brown ve Brooks, 1991); kariyer merakı, eğitim olanaklarını ve meslek seçeneklerini değerlendirmeyi (Blustein, 1992); kariyer güveni ise, sorunları ele alıp çözebilme ve sorunlara yönelik öz yeterliliği ifade etmektedir (Hartung, Porfeli ve Vondracek, 2008). Literatür incelendiğinde kariyer uyum yeteneğinin farklı değişkenlerle ilişkisini araştıran çalışmalar bulunmaktadır. Kariyer uyum yeteneği ile eleştirel düşünme becerileri (Günay ve Çarıkçı, 2018), kariyer kararı verme öz yetkinliği ve kullanımı (Douglas, 2015), kariyer planlaması ve öz düzenleme (Creed, 2009), mesleki iyi oluş (Maggiori, 2013), proaktif kişilik ve kariyer iyimserliği (Tolentino, 2014) ile ilişkili olduğu görülmektedir. Patton ve Lokan (2001) yaptıkları çalışmada kariyer uyum yeteneğinin yaşla, cinsiyetle ve iş deneyimiyle ilişkili olduğunu belirlemişlerdir. Başka bir çalışmada ise kariyer uyum yeteneğinin ergen gelişimine pozitif etkisinin olduğu ve lise öğrencileri ile yapılan çalışmalarda kariyer oryantasyonunun ve hazırlığının problemleri önleyip stresi azalttığı tespit edilmiştir (Skorikov, 2007; Akt. Hirschi, 2009).

Üniversite öğrencileri içinde bulundukları dönem itibari ile okul hayatından iş hayatına geçiş sürecindedirler. Üniversite dönemi, gelecek ve eğitim hayatı için kariyer planı yapma ve kariyer belirsizliği yaşamanın yoğun olarak görüldüğü bir dönemdir (Özden ve Sertel- Berk, 2017). Öğrenciler birçok görevle karşı karşıya oldukları için streslidirler ve önemli bir kısmı da kariyerleriyle ilgili konularda zorlanma yaşarlar (Fouad, 2006). Öğrencilerin kariyerlerine yönelik yaşadıkları zorlanmalar, kariyer stresi olarak ifade edilmektedir. Kariyer stresi kariyer gelişimi ile ilişkili olmakla birlikte, kavram olarak yüksek ölçüde kariyer belirsizliği ve düşük seviyede kariyer olgunluğunu içerir (Park,Choi, Namve Lee, 2011).Goldman ve Wong (1997) yaptıkları çalışmada stres düzeyi arttıkça problem çözme becerilerinde azalma olduğunu tespit etmişlerdir. Kariyer uyum yeteneğinin değişimlerle ve zorluklarla baş etme ve problem çözme 
becerisini içerdiği düşünüldüğünde üniversite öğrencilerinin kariyer streslerinin kariyer uyum yeteneklerini azaltacağı düşünülebilir. Bu durumla paralel olarak Misra ve Castilo (2014) öğrencilerin yaşamlarında karşılaştıkları ve öğrencileri zorlayan değişimlerin akademik stresin bir boyutunu oluşturduğunu ifade etmektedirler. Yaşamdaki değişimler, artan rekabet, istihdam sorunu ve buna benzer kariyerle ilgili zorlanmalar ve duygusal sıkıntılar (kaygı, stres vb.) bireylerin kariyerlerine ilişkin bir rehbere ihtiyaç duymasına sebep olabilir. Bu noktada bireylere kariyer danışmanı olarak yardımcı olan ve genç çalışanları ve onların içinde bulunduğu sistemi de etkileyen rehberlik (mentörlük) kavramı devreye girmektedir (Mc-Mahon, Patton, 2000). Bahsedilen rehberlik tek yönlü bir kavramı değil çok yönlülüğü (danışmanlık, modellik vb.) içermektedir (Wood, 1997). Bireylere eğitim ve iş hayatlarında rehberlik etmek kariyer danışmanlığı süreci ile ilişkili olarak yürütülmekte ve bireyin farklı yaşam rolleri için fayda sağlamaktadır (Anafarta, 2002). Mentörlük olarak adlandırılan bu ilişkide, deneyimli, tecrübeli, bilgi sahibi kişi (mentor) ile tecrübe eksikliği yaşayan bilgilendirmeye ve rehberliğe ihtiyaç duyan birey (mentee) arasında karşılıklı ve iş birliğine dayalı bir süreç yaşanmaktadır (Çınar, 2010). Mentörlük ilişkisi kişin gelişimi ve başarısına odaklanan, kariyer gelişimi gibi konularda yardım ve yol göstericilik faaliyetlerini ifade etmektedir (Jacobi, 1991). Mentörlük öğrencinin kişiliğin gelişmesinde, beceriler edinmesinde, sorumluluk sahibi olup bağımsızlığını kazanmasında etkilidir. Bu olumlu etkilerin öğrencilere ulaşabilmesi için mentörlüğün üniversitelerde kurumsallaştırılması gerektiğinden bahsedilmektedir (Tunçay, 2014). Ancak yurt içi literatür incelendiğinde kariyer danışmanlığı ve rehberlik ile ilgili çalışmaların çoğunlukla iş hayatında gerçekleştirildiği (Anafarta, 2002), yükseköğretimde ise rehberlik hizmetlerinin gelişmediği ve üniversite öğrencilerine ise bu hizmetlerin nadiren sunulduğu görülmektedir (Gök ve Aydın, 2017).Nitekim Akoğlan-Kozak ve Dalkıranoğlu, (2013) mezun olan ön lisans ve lisans öğrencisi ile yaptıkları çalışmada öğrencilere, kariyer kararı vermede gerekli düzeyde rehberlik edilmediği, kariyer kararlarını geleneksel düşüncelere göre verdikleri, ekonomik kaygıların daha ön planda olduğu, lisans üstü eğitim almayı kariyer olanağı olarak gördükleri, kariyerle ilgili bilgi veren siteler hakkında bilgi sahibi oldukları sonucuna ulaşmışlardır. Kariyer gelişimi; kendini düzenleme ve yönetmeyle ilgili birçok süreci beraberinde getirir. Mentörlük ise kariyer doyumunu sağlayan, bireyin psikososyal süreçlerde kendini geliştirmesine yönelik fırsatlar sunan ve kişiye destek olan bir hizmettir (Murphy ve Ensher, 2001). Bu bağlamda mentörlük hizmetinin mesleğe hazırlanma sürecindeki genç bireyler için önemli bir destek hizmeti olduğunu söylemek mümkündür.

Literatür incelendiğinde üniversite öğrencileri için önemli olan kariyer stresi, kariyer uyum yetenekleri ve öğrencilere sunulan mentörlük arasındaki ilişkiyi inceleyen çalışmaların olmadığı görülmektedir. Bu bağlamda çalışma orijinal bir çalışmadır. Yükseköğretim öğrencileri, içinde bulundukları dönem itibariyle hem akademik hem de kariyer gelişimine ilişkin görevleri yerine getirmelidirler. Bu dönemde öğrencilerin stres düzeylerinin yüksek olduğu göz önünde bulundurulduğunda ve kariyer uyum yeteneklerinin de baş etme ve problem çözme becerilerini, değişimlere ayak uydurmayı, karar verme hazırlığını içerdiği düşünüldüğünde öğrencilerin kariyer gelişimleri ile ilgili kavramların birbiriyle ilişkisinin belirlenmesi, öğrencilerin kariyer gelişimlerine yönelik yapılacak çalışmaların planlanmasına yardımcı olacaktır. Bununla birlikte bireylerin kendilerini ayarlamalarını sağlayarak, yaşam planları ile ilgili bireyleri harekete geçiren ve kariyere bağı belirsizlikleri azaltıp kariyere ilişkin stresi azaltmaya yardımcı olacağı düşünülen mentörlük de incelenmelidir. Bu açıdan çalışma işlevsel bir çalışmadır.

2017 nüfus istatistiklerine göre Türkiye' de çalışma yaşamında yer alabilecek 15-64 yaş aralığındaki kişi sayısı 54881 652'dir (TUiK, 2014). Yükseköğretim Kurumu istatistiklerine göre Türkiye'de 2017-2018 yılında 2768757 ön lisans; 4 241841 lisans, 454673 yüksek lisans ve 95100 doktora öğrencisi bulunmaktadır (YÖK, 2018). 2017 yılında 15-64 yaş aralığında yükseköğretim mezunlarında işsizlik oranı ise \%12,7'dir (TUiK, 2018). Bu veriler göz önünde bulundurulduğunda Türkiye gibi genç nüfus oranı yüksek olan bir ülkede, üniversite öğrencilerinin kariyerlerine ilişkin daha yoğun bir kaygı yaşayabileceklerini söylemek yanlış olmayacaktır. Çalışmanın katılımcılarını eğitim fakültesi öğrencileri oluşturmaktadır. Eğitim fakültesi öğrencileri için de benzer bir tablonun söz konusu olduğunu söylemek mümkündür.

YÖK (2018) verilerine göre Türkiye'de 72 üniversitede eğitim fakültesi bulunmaktadır. Bu fakültelerin neredeyse hepsinde psikolojik danışma ve rehberlik (pdr), sını öğretmenliği, özel eğitim öğretmenliği, İngilizce öğretmenliği, Almanca öğretmenliği, matematik öğretmenliği, bilgisayar ve öğretim teknolojileri öğretmenliği (böte), sosyal bilgiler öğretmenliği, Türkçe öğretmenliği bölümleri bulunmaktadır. Eğitim fakültesi mezunlarının çalışmak için ilk tercihleri genellikle Milli Eğitim Bakanlığı'na bağlı devlet okullarıdır. Tümerdem'in 2007 yıında yaptığı çalışmada Fen Fakültesi öğrencilerinin 33'ü memur olmak isterken, Eğitim Fakültesi öğrencilerinin \% 77'sinin memur olmak istediğini belirlemiştir (Tümerdem, 2007). Aradan geçen 11 yılda bunun çok fazla değişmediği söylenebilir. Örneğin; 2018 yılında KPSS Eğitim Bilimleri sınavına giren aday sayısı 416.485'dir, 2017 yılında bu sayı 311.759'dur (ÖSYM, 2018). Bu tercihte 
özel sektörde çalışan öğretmenlerin çalışma saatlerinin ve iş yüklerinin fazla, ücretlerinin az oluşu, iş güvencelerinin olmayışının etkisi büyüktür. Bu durum öğretmen adaylarının kariyerlerine ve geleceklerine ilişkin belirsizlik ve stres yaşamalarına neden olabilmektedir. Şahin (2011) 149 öğretmen adayı ile yaptığı çalışmada katılımcıların, \%34'ünün Türkiye'nin her yerinde çalışmak istemediğini, \%81'inin mesleki gelecekleriyle ilgili olumlu düşünmediğini ve \%91'inin öğretmen olarak atanmamaları durumunda yaşamlarının etkileneceğini düşündüğünü belirlemiştir. Bu bağlamda eğitim fakültesi öğrencilerinde kariyer uyum yetenekleri ve mentörlük ile kariyer stresi arasındaki ilişkinin belirlenmesi, öğretmen adaylarıyla yapılacak kariyer gelişimine yönelik çalışmalara yardımcı olacaktır. Bu çalışma kariyer stresi ile kariyer uyum yeteneği ve mentörlük arasında ilişkiyi ve kariyer uyum yeteneği ile mentörlüğün kariyer stresini ne derece yordadığını belirlemeyi amaçlamaktadır.

\section{Yöntem}

\section{Araştırma Deseni}

Araştırma nicel araştırma yöntemleri kullanılarak yapılmıştır. Araştırmada üniversite öğrencilerinin kariyer stresleri, kariyer uyum yetenekleri ve öğrencilere sunulan mentörlük arasındaki ilişkiyi incelemek amacıyla korelasyonel model kullanılmıştır. İki veya daha fazla değişken arasındaki ilişkileri belirlemek ve neden sonuca ilişkin bilgi edinebilmek amacıyla yapılan araştırmalara korelasyonel araştırma denmektedir (Büyüköztürk vd., 2016).

\section{Çalışma Grubu}

Araştırmanın örneklemini, köklü bir araştırma üniversitesindeki eğitim fakültesinin psikolojik danışma ve rehberlik (pdr), sınıf öğretmenliği, özel eğitim öğretmenliği, İngilizce öğretmenliği, Almanca öğretmenliği, matematik öğretmenliği, bilgisayar ve öğretim teknolojileri öğretmenliği (böte), sosyal bilgiler öğretmenliği, Türkçe öğretmenliği bölümlerinde öğrenim gören ve uygun örnekleme yöntemiyle belirlenen284(213 kadın, 71 erkek) üniversite öğrencisi oluşturmaktadır. Araştırma grubunun yaş aralı̆̆ı 19-37 ve yaş ortalaması 22,14'tür.Öğrencilerin bölümlere göre dağılımı Tablo 1'de verilmiştir.

\section{Tablo 1. Öğrencilerin Bölümlere Göre Dağılımı}

\begin{tabular}{lcc}
\hline Bölüm & $f$ & $\%$ \\
\hline PDR & 50 & 17,6 \\
Sınıf öğretmenliği & 20 & 7,0 \\
Özel eğitim öğretmenliği & 22 & 7,7 \\
Bilgisayar ve öğretim teknolojileri öğretmenliği & 31 & 10,9 \\
Türkçe öğretmenliği & 31 & 10,9 \\
İngilizce öğretmenliği & 47 & 16,5 \\
Almanca öğretmenliği & 34 & 12,0 \\
Matematik öğretmenliği & 29 & 10,2 \\
Sosyal bilgiler öğretmenliği & 20 & 7,0 \\
Toplam & 284100,0 \\
\hline
\end{tabular}

\section{Veri Toplama Araçları}

Kariyer stresi ölçeği (KSÖ):Choi ve arkadaşları (2011) tarafından üniversite öğrencilerinin kariyerlerine yönelik stres kaynaklarını ölçmek amacı ile geliştirilmiştir. Ölçeğin Türkçe 'ye uyarlamasını Özden ve Sertel-Berk (2017) yapmıştır. 20 maddeden oluşan ölçeğin, kariyer belirsizliği ve bilgi eksikliği, iş bulma baskısı ve dışsal çatışmadan oluşan üç alt ölçeği bulunmaktadır. İç tutarlılık güvenirliği için hesaplanan Cronbach Alfa katsayıları kariyer belirsizliği ve bilgi eksikliği için .94, iş bulma baskısı için .86 ve dışsal çatışma için .83 olarak bulunmuştur. Bu araştırmada ise kariyer belirsizliği ve bilgi eksikliği için .89 , iş bulma baskısı için .84 ve dışsal çatışma için .78 olarak bulunmuştur.

Kariyer uyum yetenekleri ölçeği (KUYÖ): Kariyer uyum yeteneklerini belirlemek için Savickas ve Porfeli (2012) tarafından geliştirilmiş, Türkçeye uyarlama çalışmaları Kanten (2012) tarafından yapılmıştır. Ölçek, kaygı, kontrol, merak ve güven olmak üzere dört alt ölçek ve 19 maddeden oluşan, beşli likert tipi bir ölçektir. İç tutarlılık için hesaplanan Cronbach Alfa katsayıları kaygı için .61, kontrol için .77, merak için .79 ve güven için .81 olarak bulunmuştur. Bu araştırmada ise kaygı için .83, kontrol için .77, merak için .83 ve güven için .85 olarak bulunmuştur.

Yükseköğretim öğrenci mentörlük ölçeği (YÖMÖ):Crisp (2009) tarafından geliştirilmiş ve Gök ve Aydın (2017) tarafından Türkçe'ye uyarlanmıştır. Toplamda 19 maddeden oluşan ölçek dört alt ölçekten oluşmaktadır. Alt boyutlar; psikolojik ve duygusal destek, derece ve kariyer desteği, akademik alan bilgisi desteği ve rol modelin varlığıdır. Alt 
boyutların Cronbach alfa güvenirliği sırasıyla $.84, .80, .77, .80$ olarak hesaplanmıştır. Bu araştırmada ise sırasıyla .84 , $.87, .84, .83$ olarak hesaplanmıştır.

\section{Verilerin Analizi}

Verilerin analizi SPPS programında yapılmıştır. Araştırma soruları .05 anlamlılık seviyesinde test edilmiştir. Veriler iki aşamada analiz edilmiştir. İlk aşamada veriler eksik değer, aykırı değer, normallik, çoklu doğrusal bağlantı açısından incelenmiştir. Veriler hatalı kodlama açısından incelenmiş ve formları boş bırakan katıımcıların ölçekleri değerlendirme dışı bırakılmıştır. İkinci aşamada eksik değer analizi yapılarak ve boş kalan maddelerin yerine serilerin ortalaması yoluyla veri atanmıştır. Aykırı değer analizinde Mahalonobis uzaklık değerine bakılmış 19.675'ten büyük 63 veri analiz dışında tutulmuştur. Son aşamada çoklu doğrusal bağlantı için VIF ve tolerans değerleri incelenmiştir. Alan yazında VIF değeri 10'a eşit ya da 10'dan büyükse (Birkez ve Dodge, 1993; Akt. Vupa ve Gürünlü Alma, 2008) ve tolerans değerinin .10'danküçük olması durumunda anlamlı çoklu doğrusal bağlantı problemi söz konusu olduğu belirtilmektedir. Değişkenler arasında çoklu doğrusal bağlantı bulunmamıştır. Yapılan incelemeler sonucunda analiz için gerekli sayıltıları karşılayan 284 veri ile analizler yapılmıştır. Araştırmada değişkenler arasındaki ilişkileri tespit etmek için pearson momentler çarpım korelasyonu; kariyer uyum yetenekleri ve mentörlük hizmetinin üniversite öğrencilerinin kariyer streslerini açıklama gücünü belirlemek için çoklu regresyon analizi kullanılmıştır.

\section{Bulgular}

Eğitim fakültesi öğrencilerinin kariyer stresi ölçeği alt ölçek puanları ile kariyer uyum yetenekleri ölçeği alt ölçek puanları arasında anlamlı bir ilişki olup olmadığını belirlemek amacıyla Pearson Korelasyon analizi yapılmıştır, sonuçları Tablo 2'de verilmiştir.

\section{Tablo 2. Kariyer Stresi Alt Ölçekleri ile Kariyer Uyum Yetenekleri Alt Ölçekleri Arasındaki Korelasyon Sonuçları}

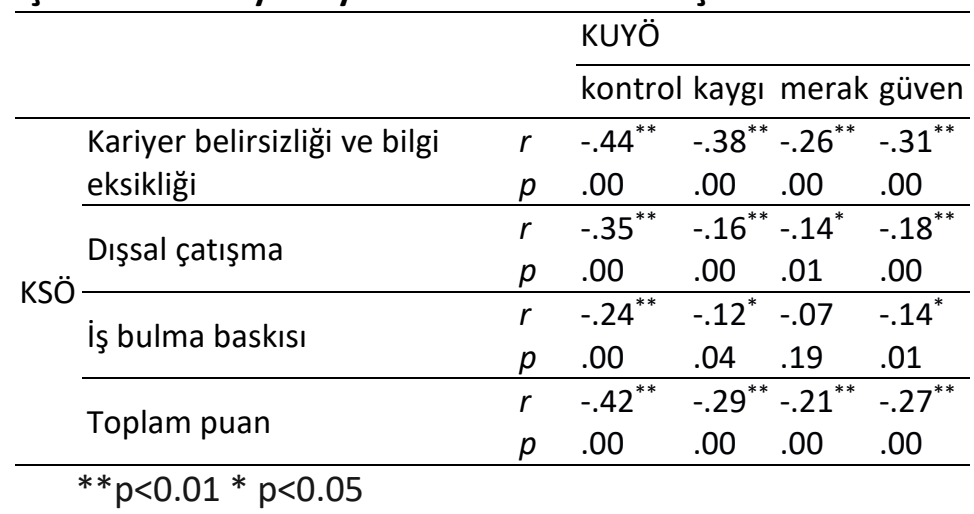

Tablo 2'deki korelasyon sonuçları incelendiğinde KSÖ’nün kariyer belirsizliği ve bilgi eksikliği alt ölçek puanı ile KUYÖ’nün kaygı ( $r=-.38)$, kontrol ( $r=-.44)$ ve güven ( $r=-.31$ ) alt ölçek puanları arasında orta düzeyde, merak $(r=-.26)$ alt ölçeği puanı ile düşük düzeyde anlamlı bir ilişki bulunmuştur ( $p<.01)$. KSÖ'nün dışsal çatışma alt ölçek puanı ile KUYÖ'nün kaygı ( $r=-.16)$, merak ( $r=-.14)$ ve güven $(r=-.18)$ alt ölçek puanları arasında düşük düzeyde, kontrol $(r=-.35)$ alt ölçeği puanı ile orta düzeyde anlamlı ilişki bulunmuştur. KSÖ’nüniş bulma baskısı alt ölçek puanı ile KUYÖ’nün sırasıyla kontrol, kaygı ve güven alt ölçek puanları arasında düşük düzeyde $(r=-.24,-.12,-.14)$ anlamlı ilişki tespit edilmiştir(p<.05, p<.01). KSÖ’nün toplam puanı ile KUYÖ’nün sırasıyla kaygı, merak ve güven alt ölçek puanları arasında düşük düzeyde ( $r=-.29,-.21,-.27)$, kontrol alt ölçek puanı ile orta düzeyde ( $r=-.42$ ) anlamlı ilişki bulunmuştur ( $p<.01)$.

Eğitim fakültesi öğrencilerinin yükseköğretim mentörlük ölçeği alt ölçek puanları ile kariyer stresi ölçeği alt ölçek puanları arasında anlamlı bir ilişki olup olmadığını belirlemek amacıyla Pearson Korelasyon analizi yapılmıştır, sonuçları Tablo 3'te verilmiştir. 
Tablo 3.Yüksek Öğretim Mentörlük Ölçeği Alt Ölçekleri ile Kariyer Stresi Alt Ölçekleri Arasındaki Korelasyon Sonuçları

\begin{tabular}{|c|c|c|c|c|c|}
\hline & & \multicolumn{4}{|c|}{ YÖMÖ } \\
\hline & & $\begin{array}{c}\text { psikolojik-duygusal } \\
\text { destek }\end{array}$ & $\begin{array}{c}\text { derece ve kariyer } \\
\text { desteği }\end{array}$ & $\begin{array}{c}\text { akademik alan bilgisi } \\
\text { desteği }\end{array}$ & $\begin{array}{l}\text { rol model } \\
\text { varlığı }\end{array}$ \\
\hline \multirow{2}{*}{$\begin{array}{l}\text { kariyer belirsizliği ve bilgi } \\
\text { eksikliği }\end{array}$} & $r$ &,$- 14^{*}$ &,$- 17^{* *}$ &,$- 14^{*}$ &,- 09 \\
\hline & $p$ & ,01 &, 00 &, 01 &, 12 \\
\hline \multirow{2}{*}{ dışsal çatışma } & $r$ &,- 02 &,$- 21^{* *}$ &,$- 13^{*}$ &,$- 15^{* *}$ \\
\hline & $p$ &, 63 & ,00 &, 02 &, 00 \\
\hline \multirow{2}{*}{ KSÖ } & $r$ &,- 09 &,- 08 &,- 10 &,- 02 \\
\hline & $p$ & ,09 &, 15 &, 07 &, 68 \\
\hline \multirow{2}{*}{ toplam } & $r$ &,$- 12^{*}$ &,$- 18^{* *}$ &,$- 15^{* *}$ &,- 09 \\
\hline & $p$ & ,03 &, 00 & ,01 & ,09 \\
\hline
\end{tabular}

${ }^{* * p}<0.01 * p<0.05$

Tablo 3'teki korelasyon sonuçlarına bakıldığında KSÖ'nün kariyer belirsizliği ve bilgi eksikliği alt ölçek puanı ile YÖMÖ’nün psikolojik ve duygusal destek, derece ve kariyer desteği ve akademik alan bilgisi desteği alt ölçek puanları arasında düşük düzeyde ( $r=-.14,-.17,-.14)$ anlamlı ilişki bulunmuştur $(p<.01)$. KSÖ’nün dışsal çatışma alt ölçek puanı ile YÖMÖ’nün derece ve kariyer desteği, akademik alan bilgisi desteği ve rol model varlığı alt ölç̧ek puanları arasında düşük düzeyde $(r=-.21,-.13,-.15)$ anlamlı ilişki bulunmuştur $(p<.01, p<.05)$. KSÖ toplam puanı ile YÖMÖ’nün psikolojik ve duygusal destek, derece ve kariyer desteği ve akademik alan bilgisi desteği alt ölçek puanları arasında düşük düzeyde $(r=-.12,-.18,-.15)$ anlamlı ilişki bulunmuştur $(p<.05)$.

Eğitim fakültesi öğrencilerinin kariyer stresi ölçeğinden aldıkları puanı, kariyer uyum yetenekleri alt ölçek puanları ile yükseköğretim mentörlük ölçeği alt ölçek puanlarının yordama gücünü belirlemek için çoklu regresyon analizi yapılmıştır. Sonuçlar Tablo 4'te verilmiştir.

Tablo 4.Üniversite Öğrencilerinin Kariyer Stresi Ölçek Puanının Yordayıcılarına iliş̧kin Çoklu Regresyon Analizi Sonuçları

\begin{tabular}{llccccc}
\hline \multicolumn{2}{l}{ Değişkenler } & $B$ & $S E_{B}$ & $b$ & $t$ & $p$ \\
\hline \multirow{4}{*}{ KUYÖ } & Kontrol & -1.951 & .373 & -.373 & -5.233 & $.000^{* *}$ \\
& Kaygı & -.801 & .385 & -.145 & -2.079 & $.039^{*}$ \\
& Merak & .330 & .281 & .090 & 1.174 & .241 \\
& Güven & -.130 & .310 & -.030 & -.419 & .676 \\
\hline \multirow{4}{*}{ YÖMÖ } & Psikolojik duygusal destek & -.025 & .171 & -.013 & -.146 & .884 \\
& Derece ve kariyer desteği & -.180 & .213 & -.084 & -.845 & .399 \\
& Akademik alan bilgisi desteği & -.240 & .261 & -.093 & -.919 & .359 \\
& Rol model varlığı & .337 & .277 & .109 & 1.217 & .225 \\
\hline
\end{tabular}

Bağımlı Değişken: KSÖ, $\mathrm{R}^{2}=.21$, Adjusted $\mathrm{R}^{2}=.18 \mathrm{~F}=9.24 * \mathrm{*}<0.01 * \mathrm{p}<0.05$

Tablo 4'e bakıldığında KUYÖ'nün kaygı ve kontrol alt ölçek puanları, KSÖ’ye ilişkin toplam varyansın \%18'ini(R=0.46, $\left.R^{2}=0.18, F=9.24 p<0.05\right)$ açıklamaktadır. Çoklu regresyon analizi sonuçları incelendiğinde KUYÖ’nün kontrol ( $(=-.37)$ ve kaygı ( $(=-.14)$ alt ölçek puanlarının kariyer stresi üzerinde önemli bir yordayıcı olduğu görülmektedir ( $p<.05)$.

\section{Tartışma, Sonuç ve Öneriler}

Araştırma sonucunda üniversite öğrencilerinin kariyer uyum yetenekleri, kariyer stresleri ve öğrencilere sunulan mentörlük hizmetleri arasında anlamlı ilişki bulunmuştur. KSÖ’nün kariyer belirsizliği ve bilgi eksikliği alt ölçek puanı ile KUYÖ’nün kaygı, kontrol ve güven alt ölçek puanları arasında orta düzeyde, merak alt ölçeği puanı ile düşük düzeyde anlamlı bir ilişki bulunmuştur. KSÖ’nün dışsal çatışma alt ölçek puanı ile KUYÖ'nün kaygı, merak ve güven alt ölçek puanları arasında düşük düzeyde, kontrol alt ölçeği puanı ile orta düzeyde anlamlı ilişki bulunmuştur. KSÖ’nün iş bulma baskısı alt ölçek puanı ile KUYÖ’nün kontrol, kaygı ve güven alt ölçek puanları arasında düşük düzeyde anlamlı ilişki tespit edilmiştir. KSÖ’nün toplam puanı ile KUYÖ’nün kaygı, merak ve güven alt ölçek puanları arasında düşük düzeyde, kontrol alt ölçek puanı ile orta düzeyde anlamlı ilişki bulunmuştur.

KSÖ’nün kariyer belirsizliği ve bilgi eksikliği alt ölçek puanı ile YÖMÖ’nün psikolojik ve duygusal destek, derece ve kariyer desteği ve akademik alan bilgisi desteği alt ölçek puanları arasında düşük düzeyde anlamlı ilişki bulunmuştur. KSÖ’nün dışsal çatışma alt ölçek puanı ile YÖMÖ’nün derece ve kariyer desteği, akademik alan bilgisi desteği ve rol 
model varlığı alt ölçek puanları arasında düşük düzeyde anlamlı ilişki bulunmuştur. KSÖ toplam puanı ile YÖMÖ’nün psikolojik ve duygusal destek, derece ve kariyer desteği ve akademik alan bilgisi desteği alt ölçek puanları arasında düşük düzeyde anlamlı ilişki bulunmuştur. Kariyer uyum yeteneklerinin ve yüksek öğretim öğrenci mentörlüğünün, kariyer stresini anlamlı düzeyde yordadığı tespit edilmiştir. KUYÖ’nün kaygı ve kontrol alt ölçek puanlarının, KSÖ’ye ilişkin toplam varyansın \%18'ini açıkladığı belirlenmiştir.

Bireylerin kariyerlerini benimsemeleri, anlamlandırmaları, meslekte çalışanları kendilerine rol model almaları, üniversite yaşamından iş yaşamına geçişte streslerini fark edip stresleriyle baş etmeleri önemli görülmektedir. Super (1990) mesleki gelişim kuramında bireylerin meslek yaşamlarında maksi ve mini döngülerin olduğunu ve bu döngüler sürecinde mesleklerini değiştirme kararı alabildiklerini ifade etmektedir. Özellikle yüksek öğretim yılları gelişim dönemi itibariyle meslek ve kariyer kararı vermede oldukça önemli bir dönemdir. Nitekim Havighurst (1956) gelişim dönemlerine göre yerine getirilmesi gereken gelişim görevlerinden bahsederken genç yetişkinlik dönemindeki bireylerin (19-29 yaş) bir işe girme ve kariyerinde ilerleme görevlerini yerine getirmelerinin önemli olduğundan bahsetmiştir. Bireylerin kariyerleri her türlü yeniliğe açık olduğundan ve okul-iş ve iş-iş geçişleri her zaman var olabileceğinden geçişlere uyum sağlamak önemlidir.

Çalışma sonucunda kariyer uyum yetenekleri, yükseköğretim mentörlüğü ile kariyer stresi arasında anlamlı ilişki belirlenmiştir. Çalışma sonucuyla benzer olarak Stoltz, Wolf, Monroe, Mazahreh ve Farris (2013) yaptıkları çalışmada kariyer uyumluluğu, stresle baş etme, kişilik özellikleri, çok yönlü ve sınırsız düşünce yapısı arasında ilişki olduğunu sonucunu elde etmiştir. Viannen, Peter ve Preenen (2009) çalışmasında genç yetişkinlerin herhangi bir iş veya kariyere karar verme sürecinde stres yaşadıklarını ve stresin kariyer gelişimini etkilediğini ifade etmiştir. Ross, Niebling, Heckert'un (1999) üniversite öğrencilerinin stres kaynaklarını incelediği çalışmasında akademik stresörler içerisinde iş bulma-arama ve iş yaşamındaki değişiklikler bulunmaktadır. Park, Choi, Nam ve Lee (2011)kariyer stresinin kariyer tutum olgunluğu ile ilişkili olduğunu tespit etmiştir. Yowell, Peterson, Leardon, Leirer ve Reed (2011) kariyer ve yaşam stresinin olumsuz kariyer inançlarıyla ilişkili olduğunu belirtmiştir. Başka bir çalışmada ise üniversite öğrencileri kariyere ilişkin streslerini genel stres kaynakları içinde ilk sırada ifade etmiştir (Jang, 2000; Kim, 2003; Akt. Özden, Sertel-Berk, 2017). Mathew (2017) üniversite öğrencilerinin stresle baş etme stratejileri arasında bir kariyere başlama ve kariyer anlayışına sahip olma yeteneğinin etkili olduğundan bahsetmiştir. Bununla birlikte yurt içi literatüründe kariyer uyum yetenekleri, mentörlükve kariyer stresini birlikte ele alan herhangi bir çalışma bulunmamaktadır. Yurt dışı literatürde ise Yang ve arkadaşları (2011) çalışmalarında bireylerin mentörlük hizmeti almasının stresle baş etmede önemli bir faktör olduğunu tespit etmiştir. Çalışma sonucuna benzer şekilde Baugh ve Sullivan (2015) mentörlük hizmetinin kariyer başarııını artırdığını tespit etmiştir. Curtin, Malley ve Stewart (2016) psikososyal ve araçsal mentörlüğün bireylerin kariyerleriyle ilgili öz yetkinlikleri üzerinde dolaylı olarak etkili olduğunu ifade etmiştir. Bu açıdan çalışmanın bulguları literatür bulgularıyla benzerlik göstermektedir. Çalışmaya katılan eğitim fakültesi öğrencileri için mezuniyet sonrası yapabilecekleri işler ve çalışabilecekleri kurumlar sınırlıdır. Dolayısıyla eğitim fakültesi öğrencileri iş ve çalışabilecekleri kurumlara ilişkin daha fazla bilgi ve tecrübe sahibidirler. Çalışacakları kurumlara ilişkin diğer bölümlere göre daha az belirsizlik yaşarlar. Bu nedenle kariyer uyum yeteneklerinin artması, kariyerlerine ilişkin daha az stres yaşamalarına imkân sağlıyor olabilir.

Çalışmada kariyer uyum yeteneğinin kontrol ve kaygı alt ölçek puanlarının kariyer stresini yordadığı tespit edilmiştir. Diğer değişkenlerin ise modele anlamlı bir katkısı bulunmamıştır. Daha önce de belirtildiği gibi öğretmenlik yapılacak işin ve çalışılacak kuruluşların daha sınırlı ve belli olduğu bir meslektir. Öğrenciler yıllardır süren öğrencilikleri nedeniyle okul sistemine ve işleyişine yabancı değillerdir. Staj, gözlem ve çeşitli uygulamalar için gittikleri okullarda da bunu bir öğretmen olarak gözlemleme ve değerlendirme imkanına sahiptirler. Bu nedenle eğitim fakültesi öğrencilerinin kariyerlerine ilişkin daha fazla bilgi sahibidirler. Bu konudaki belirsizlikleri daha az olduğu için de kariyer merakı ve kariyer güveni alt ölçek puanlarının kariyer stresini yordamadığı düşünülmektedir. Eğitim fakültesi öğrencileri, diğer pek çok fakülte öğrencileri ile kıyaslandığında daha az sayıda öğrencini olduğu sınıflarda, daha yoğun etkileşim içindedirler. Bu durum hem okul, ders, akademik başarı, kpss sınavı, sınava hazırlanma, atanma, çalışılabilecek alternatif kurumlar gibi konularda akran desteği almalarına; hem de ders sorumlusu akademisyenlerden psikolojik destek, alan bilgisi, rol model olma konularında yardım sağlama açısından avantaj yaratıyor olabilir. Öğrenciler bu durumu eğitim yaşantılarının doğal bir parçası olarak algılamıyor, mentörlük hizmeti olarak değerlendirmiyor olabilirler. 
Üniversite öğrencileri içinde bulundukları dönem itibariyle kariyere ilişkin konularda daha çok stres altındadır ve bu konularda öğrencilere verilecek hizmetler önemlidir. Bu çalışma eğitim fakültesi öğrencileriyle sınırlıdır. Çalışma alanları daha fazla çeşitlilik gösteren diğer fakültelerin bölümleri ile de çalışma tekrarlanabilir. Örneğin, meslek yüksek okullarının meslek edindirme ve uygulamaya yönelik rolü düşünüldüğünde çalışmadaki değişkenlerin bu örneklem grubunda tekrar çalışması önerilebilir.

Çalışma üçüncü ve dördüncü sınıf öğrencileriyle gerçekleştirilmiştir, farklı bir çalışmada diğer sınıf düzeyindeki öğrenciler de örnekleme katılabilir. Havighurst (1956)'un gelişim dönemleri için belirlediği görevler incelendiğinde orta öğretim dönemi meslek seçiminde önemli bir aşama olarak görülmektedir. Dolayısıyla bu dönemdeki öğrencilere doğru yönlendirmeler yapılması ve meslek seçim aşamasındaki streslerinin belirlenmesinin faydalı olacağı düşünülmektedir.

Çalışmada kariyer stresi ile kariyer uyum yetenekleri ve mentörlük hizmetleri arasında düşük ve orta düzeyde ilişki olduğu; kariyer uyum yeteneğinin kontrol ve kaygı alt ölçek puanlarının kariyer stresinin anlamlı yordayıcıları olduğu belirlenmiştir. Eğitim fakültesi öğrencilerinin kariyer streslerini etkileyen diğer değişkenlere ilişkin kapsamlı bilgi edinmek için kariyer stresi yüksek ve düşük öğrencilerle yapılacak derinlemesine görüşmeleri içeren nitel çalışmalar yapılabilir.

\section{Kaynakça}

Akoğlan-Kozak, M.\& Dalkıranoğlu, T. (2013). Mezun öğrencilerin kariyer algılamaları: Anadolu Üniversitesi örneği. Anadolu Üniversitesi Sosyal Bilimler Dergisi, 13(1), 41-52.

Anafarta, N. (2002). Bireysel kariyer danışmanı olarak rehber (mentor). Cumhuriyet Üniversitesi iktisadi ve Idari Bilimler Dergisi, $3(1), 2002$.

Bagshaw, M. (1998). Coaching, mentoring and the sibling organization. Industrial and Commercial Training, 30, 87-89.

Baugh, S. G.\&Sullivan, S. E. (2005). Mentoring and career development. Career Development International, 10, 425-428.

Baumeister, R. F. \& Vohs, K. D. (2007). Self-regulation, ego depletion, and motivation. Socialand Personality Psychology Compass, 115-128.

Blustein, D. L. (1992). Applying current theory and research in career exploration to practice. The CareerDevelopment Quarterly,41, 174-184.

Brown, D. \& Brooks, L. (1991). Career counseling techniques. Boston: Allynand Bacon.

Büyüköztürk, Ş., KIlıç Çakmak, E., Akgün, Ö. E., Karadeniz, Ş. \& Demirel, F. (2016).Korelasyonel araştırmalar. Bilimsel Araştırma Yöntemleri (22. Baskı) içinde (ss. 184-189). Ankara: Pegem Akademi.

Choi, B. Y., Park, H. R., Nam, S. K., Lee, J., ..., \& Lee, S. M. (2011). The development and initial psychometric evaluation of the Korean Career Stress Inventory for college students. Career Development Quarterly, 59, 559-572.

Creed, P. A., Fallon, T. \& Hood, M. (2009). The relationship between career adaptability, person and situation variables, and career concerns in young adults. Journal of Vocational Behavior, 74, 219-229.

Crisp, G. (2009). Conceptualization and initial validation of the college student mentoring scale. Journal of College Student Development, 50(2), 177-194.

Curtin, N., Malley, J. \& Stewart, A. J. (2016). Mentoring then extgeneration of faculty: supporting academic career aspirations among doctoral students. Res High Educ, 57, 714-738.

Çınar, Z. (2010). Coaching and mentoring. Ekonomi, Sosyoloji ve Politika Dergisi, 3(1), 16-18.

Douglas, R. P. \& Duffy, R. D. (2015).Calling and career adaptability among undergraduate students. Journal of Vocational Behavior, $86,58-65$.

Fouad, N., Guillen, A., Harris-Hodge, E., Henry, C., Novakovic, A., Terry, S., \& Kantamneni, N. (2006). Needs, awareness and use of career services for college students. Journal of career assessment, 14, 407-420.

Goldman, C. S.\& Wong, E.H. (1997). Stress and the college student. Education, 117, 604-610.

Gök, E. ve Aydın, B. (2017). Yükseköğretim öğrenci mentörlük ölçeği geliştirme yolunda pilotbir çalışma. Kırıkkale Üniversitesi Sosyal Bilimler Dergisi, 7(1), 107-120.

Günay, Ö. ve Çarıkçı, İ. H. (2018). Eleştirel düşünme becerileri ile kariyer uyum yetenekleri arasındaki ilişkinin incelenmesi: Üniversite öğrencileri üzerine bir araştırma. Uluslararası iktisadi ve idari Incelemeler Dergisi, 427-440.

Hall, D., T. (2002). A working definition of career. Careers in andOut of Organizationsiçinde (ss. 11-12). Sage Publications:California.

Hartung, P.J., Porfeli, E. J.\& Vondracek, F. W. (2008). Career adaptability in childhood. The Career Development Quarterly,57,6374.

Havighurst, R. J. (1956). Research on the developmental-task concept. TheUniversity of Chicago Press, 64, 215-223.

Hirschi, A. (2009). Career adaptability development in adolesence: multiple predictors and effect on sense of power and life satisfaction. Journal of Vocational Behavior, 74,145-155.

Jacobi, M., (1991). Mentoring and undergraduate academic success: A literatüre review, Review of Educational Research, 61, 503532. 
Johnson, M. K.\& Mortimer, J. T. (2002). Career choice and development. Introduction to theories of careerdevelopment and choice içinde (ss. 3-37). SanFrancisco: Jossey-Bass.

Kahya, V. \& Ceylan, E. (2018). Üniversite öğrencilerinin bölümleri ile kariyer uyum yetenekleri arasındaki ilişkiyi belirlemeye yönelik bir araştırma. Global Business ResearchCongress (25-27 Ekim 2018) Bildirileri içinde $\quad$ (ss.217- 222).

Maggiori, C., Johnston, C. S., Krings, F., Massoidi, K. \& Rossier, J. (2013). The role of career adaptability and work conditions on general and professional well being. Journal of VocationalBehavior, 83, 437-449.

Mathew, C. P. (2017). Stress and coping strategies among college students. Journal Of Humanities And Social Science, 8, 4044.

McMahon, M. \& Patton, W. (2000). Career counsellors, support and life long learning: A case for clinical supervision. International Journal for the Advancement of Counselling, 22, 157-169.

Misra, R. \& Castillo, L. G. (2014). Academic stress among college students: Comparison of american and international students. International Journal of Stress Management, 11, 132-148.

Murphy, S. E. \& Ensher, E. A. (2001). The role of mentoring support and self-management strategies on reported career outcomes. Journal of Career Development, 27, 229-246.

ÖSYM (2018). 2018 KPSS Lisans (Genel Yetenek - Genel Kültür, Eğitim Bilimleri, Alan Bilgisi,ÖABT).Oturumlara Göre Aday Sayıları. https://dokuman.osym.gov.tr/pdfdokuman/2018/KPSS/SayisalBilgiler29082018.pdf adresinden alındı.

Özden, K. \& Sertel-Berk, Ö. (2017). Kariyer stresi ölçeğinin Türkçe'ye uyarlanması ve psikometrik özelliklerinin sınanması. Psikoloji Çalışmaları Dergisi, 37, 35-51.

Park, H., Choi, B. Y., Nam, S.K. \& Lee, S. M. (2011). The role of career stress in the relationship between maladaptive perfectionism and career attitude maturity in South korean undergraduates. Journal of Employment Counseling, 48, 27-36.

Patton, W. \& Lokan, J. (2001). Perspectives on Donald Super's construct of career maturity.Internat.Jnl. forEducational and Vocational Guidance, 1, 31-48.

Ross, S. E., Niebling, B. C. \& Heckert, T. M. (1999). Sources of stress among college students. College Student Journal, 33, 1-6.

Savickas, M. L. (1991). Improving career time perspective. Career Counseling Techniques içinde (ss. 236-249). Boston, MA: Allynand Bacon.

Savickas, M. L. (1997). Career adaptability: an integrative construct for life-span, life-spacetheory.The Career Development Quarterly, 45, 247-259.

Savickas, M. L.\& Porfeli, E.J. (2012). Career adapt-abilities scale: construction, reliability and measurement equivalence across 13 countries. Journal of Vocational Behavior, 80, 661-673.

Stoltz, K. B., Wolf, L. A., Monroe, A. E, Mazahreh, L. G. \& Farris, H. R. (2013). Adaptability in the work life task: life stylestresscoping, and protean /boundaryles scareer attitudes. The Journal of IndividualPsychology, 69, 66-83.

Super, D. (1990). A life span, life space approach to career development. Journal of Vocational Behaviour, 16, 282-298.

Şahin, i. (2011). Öğretmen adaylarııı öğretmen istihdamı ve mesleki geleceklerine ilişkin görüşleri. Kuram ve Uygulamada Eğitim Bilimleri, 11(3), 1167-1184.

Talentino, L. R., Garcia, P. R. J. M., Lu, V. N., Restubog, S. L. D., Bordia, P. \& Pleva, C. (2014). Career adaptation: the relation of adaptability to goal orientation, proactive personality and career optimism, Journal of Vocational Behavior, 84, 39-48.

Tuik (2018). Adrese dayalı kayıt sistemi-Yıllara, yaş grupları ve cinsiyete göre nüfus, nüfus kayıtları. http://www.tuik.gov.tr/PreTablo.do?alt_id=1059 adresinden alındı.

Tuik(2018). İsgücü istatistikleri. https://biruni.tuik.gov.tr/medas/?kn=72\&locale=tr adresinden alındı.

Tunçay, S. (2014). Eğitimde mentörlük uygulamaları üzerine bir araştırma.(Yayımlanmamış yüksek lisans tezi). Trakya Üniversitesi, Sosyal Bilimler Enstitüsü, Edirne.

Tümerdem, R. (2007). Dicle Üniversitesi Eğitim Fakültesi ve Fen - Edebiyat Fakültesi Kimya son sınıf öğrencilerinin kaygılarını etkileyen etmenler. Elektronik Sosyal Bilimler Dergisi, 20, $36-45$.

Vianen, A. E. M., Peter, I. E. D. \& Preenen, P. T. Y. (2009). Adaptable careers: Maximizing less and exploring more. The Career Development Quarterly, 57, 298-309.

Vupa, Ö. \& Gürünlü Alma, Ö. (2008). Doğrusal regresyon çözümlemesinde çoklu bağlantı probleminin sapan değer içeren küçük örneklemlerde incelenmesi. Selçuk Üniversitesi Fen Edebiyat Fakültesi Fen Dergisi, 31, 97-107.

Wood, M. (1997). Mentoring in further and higher education: learning from the literatüre.Education Training, 39, 333-343.

Yang, L., Xu, X., Allen, T. D., Shi, K., Zhang, X. \& Lou, Z. (2011). Mentoring in China:Enhanced understanding and association with occupational stress. J Bus Psychol, 26, 485-499.

Yeşilyaprak, B. (2014). Mesleki rehberlik ve kariyer danışmanlı̆ıına giriş. Mesleki Rehberlik ve Kariyer Danışmanlığı Kuramdan Uygulamaya (5. Baskı) içinde (ss. 2-39). Ankara: Pegem Akademi.

Yowell, E. B., Peterson, G. W., Reardon, R. C., Leirerer, S. J. \& Reed, C. A. (2011). Relationships among career and life stress, negative career thoughts, and career decision state: a cognitive information processing perspective. The Career Development Quarterly, 59, 302-314.

YÖK(2018). Yükseköğretim istatistikleri. https://istatistik.yok.gov.tr adresinden alındı. 